\title{
Inhibition of Aluminium Corrosion in Acidic Medium by Chrysophyllum Albidum (African Star Apple) Fruit Extract
}

\author{
I. C. Madufor, U. E. Itodoh, M. U. Obidiegwu, M. S. Nwakaudu \\ School of Engineering and Engineering Technology, Federal University of Technology, P. M. B. 1526, Owerri, \\ Nigeria.
}

\begin{abstract}
Inhibition of aluminium corrosion in $1.5 \mathrm{M} \mathrm{H}_{2} \mathrm{SO}_{4}$ solution in the absence and presence of Chrysophyllum albidum fruit extract (CAFE) at temperature range of $30-60^{\circ} \mathrm{C}$ was studied using weight loss and thermometric techniques. The fruit extract acts as an inhibitor in the acid environment. The inhibition efficiency increased with increase in inhibitor concentration but decreased with increase in temperature. The inhibiting effect of the Chrysophyllum albidum fruit extract could be attributed to the presence of some phytochemical constituents in the fruit extract which is adsorbed on the surface of the aluminium. The Chrysophyllum albidum fruit extract was found to obey Temkin adsorption isotherm at all the concentrations and temperatures studied. Thermodynamic parameters reveal that the adsorption process is spontaneous.
\end{abstract}

Keywords-Aluminium, Chrysophyllum albidum, Corrosion, Inhibition, Sulfuric acid.

\section{INTRODUCTION}

Aluminium and its alloys find extensive applications in industries where they are used in a variety of aggressive and corrosive service environments. The passive metal generally corrodes by processes related to the properties of a protective surface oxide film. The unprotected metal surface sites become exposed to the aqueous corrosive medium after the breakdown of the oxide film, which subsequently leads to a sequence of electrochemical reactions. Such processes at the bared metal surface are uniquely dependent on the environment and usually result in soluble complex formation that increases the rate of metal dissolution [1,2].

An important method to protect metal surfaces deployed in service in aqueous corrosive environments involves addition of suitable inhibitors to retard the corrosion reaction and reduce the corrosion rate. Organic compounds containing nitrogen, sulphur or oxygen have been found adequate for this purpose and their inhibiting action is widely attributed to their adsorption onto the metal/solution interface [3,4]. . Recent literature has shown that plant materials such as Azadirachta indica [5], Occimum viridis [6], Strychnos nuxvomica [7], Prosopis cineraria [8], Hibiscus sabdariffa extract [9], olives leaves [10], Datura stramonium [11], and Aloe vera extract [12] as well as Phyllantus amarus extracts [13] are effective inhibitors for metal in aggressive solutions. Literature has shown the corrosion inhibitive effectiveness of metals by Dacroydes edulis [14], Pachylobus edulis [15], Vigna unguiculata [16], Gum arabic [17], Raphia hookeri [18] and the latest on Ipomoea invulcrata [19]. Raja [20] reviewed in detail on the natural products as corrosion inhibitor.

The present work was designed as a contribution to the growing interest on environmentally benign corrosion inhibitors and to study corrosion inhibition of aluminium in $1.5 \mathrm{M} \mathrm{H}_{2} \mathrm{SO}_{4}$ solutions by fruit extract from Chrysophyllum albidum using weight loss and thermometric techniques at temperature range of $30-60^{\circ} \mathrm{C}$.

\section{EXPERIMENTAL}

Aluminium metal (purity 99.0\%) of the type AA 1050/1070 obtained from System Metals Industries Limited, Calabar, Nigeria was used for the investigation. Each sheet was $1.4 \mathrm{~mm}$ in thickness and was mechanically press cut into $5 \mathrm{~cm} \times 4 \mathrm{~cm}$ coupons. However, for surface treatment they were degreased in absolute ethanol, dried in acetone and stored in a desiccator before use in the corrosion studies.

Chrysophyllum albidum was obtained from Obollo, Udenu Local Government Area of Enugu State, Nigeria. The impurities in the Chrysophyllum albidum fruit extract, which are principally, sand, wood and some bark fibres were removed by dissolving the extract in hot 95\% ethanol following the method of Ekpe et al. [21]. The concentrations of inhibitor (fruit extract from Chrysophyllum albidum) prepared and used in the study were in the range $0.1-0.5 \mathrm{~g} / \mathrm{l}$. The concentration of $\mathrm{H}_{2} \mathrm{SO}_{4}$ (BDH supplies chemicals, England) used was $1.5 \mathrm{M}$.

\subsection{Weight loss measurements}

In the weight loss experiments, a clean weighed aluminium coupon was immersed completely in a 250 $\mathrm{ml}$ beaker containing the corrodent and inhibitors with the aid of threads. The beakers were placed in a 
thermostated bath maintained at $30-60^{\circ} \mathrm{C}$. The coupons were retrieved at $24 \mathrm{~h}$ interval progressively for $168 \mathrm{~h}$ (7 days), immersed in $70 \%$ nitric acid (specific gravity: 1.42) at room temperature for 2 minutes to remove the corrosion product, carefully scrubbed with bristle brush under running water, dried in acetone and weighed [22]. The differences in weight of the coupons were taken as the weight loss which was used to compute the corrosion rate given by [23]:

$$
\text { Corrosion rate }(\mathrm{mm} / \mathrm{yr})=\frac{876 W}{\rho A t}
$$

where $W$ is the weight loss $(\mathrm{g}), \rho$ is the density of specimen $\left(\mathrm{g} \mathrm{cm}^{-3}\right), A$ the area of specimen $\left(\mathrm{cm}^{2}\right)$ and $t$ the exposure time (h).

The inhibition efficiency of Chrysophyllum albidum fruit extract acting as inhibitor in $1.5 \mathrm{M} \mathrm{H}_{2} \mathrm{SO}_{4}$ was calculated using the following expression:

$$
I(\%)=1-\frac{W_{i_{-}}}{W_{o}} \times 100
$$

where $W_{o}$ and $W_{i}$ are the weight losses of the aluminium coupons in the absence and presence of inhibitor respectively in $\mathrm{H}_{2} \mathrm{SO}_{4}$ at the same temperature.

The degree of surface coverage $(\theta)$, which is defined as the fraction of the aluminium surface that was covered by the inhibitor was calculated from Equation (3):

$$
\theta=1-\frac{W_{i-}}{W_{o}}
$$

\subsection{Thermometric measurements}

The reaction vessel and procedure for determining the corrosion behaviour by this method has been described elsewhere by other authors [24-26]. In the thermometric technique, the corrodent $\left(\mathrm{H}_{2} \mathrm{SO}_{4}\right)$ concentration was kept at $1.5 \mathrm{M}$. The volume of test solution used was $250 \mathrm{ml}$. The initial temperature in all experiments was kept at $30^{\circ} \mathrm{C}$. The progress of corrosion reaction was monitored by determining the changes in temperature with time using a calibrated thermometer $\left(0-100^{\circ} \mathrm{C}\right)$ to the nearest $\pm 0.05^{\circ} \mathrm{C}$. This method enabled the computation of the reaction number $(R N)$ defined as:

$$
R N\left({ }^{\circ} \mathrm{C} \min ^{-1}\right)=\underline{T}_{\mathrm{m}}-T_{\mathrm{T}}
$$

where $T_{\mathrm{m}}$ and $T_{\mathrm{i}}$ are the maximum and initial temperatures respectively and $t$ is the time (min) taken to reach the maximum temperature.

The inhibition efficiency $(\% \mathrm{I})$ was evaluated from percentage reduction in the reaction number using Equation (5).

$$
\% I=\underline{R N}_{a q} \frac{-R N_{w i}}{R N_{a q}} \times 100
$$

where $R N_{a q}$ is the reaction number in the absence of inhibitor (blank solution) and $R N_{w i}$ is the reaction number in the presence of the corrodent containing studied inhibitor.

\section{RESULTS AND DISCUSSION}

\subsection{Weight loss, corrosion rate and inhibition efficiency}

The effect of addition of fruit extract from Chrysophyllum albidum at different concentrations on the corrosion of aluminium in $1.5 \mathrm{M} \mathrm{H}_{2} \mathrm{SO}_{4}$ was investigated using weight loss technique at a temperature range of $30-60^{\circ} \mathrm{C}$ after $168 \mathrm{~h}$ of immersion period. Fig. 1 shows the plot of weight losses versus time for aluminium in $1.5 \mathrm{M} \mathrm{H}_{2} \mathrm{SO}_{4}$ in the absence and presence of different concentrations of Chrysophyllum albidum fruit extract at $30^{\circ} \mathrm{C}$. Similar plots were obtained for other temperatures $\left(40-60^{\circ} \mathrm{C}\right)$.

The figure clearly shows a reduction in weight loss of the metal coupons in the presence of the inhibitor (Chrysophyllum albidum fruit extract) compared to the free acid solution (blank). Inspection of the figure further revealed that loss in weight of the coupons decreased with increase in the concentration of the inhibitor. Similar trend was observed for other temperatures but with greater values of weight loss. 


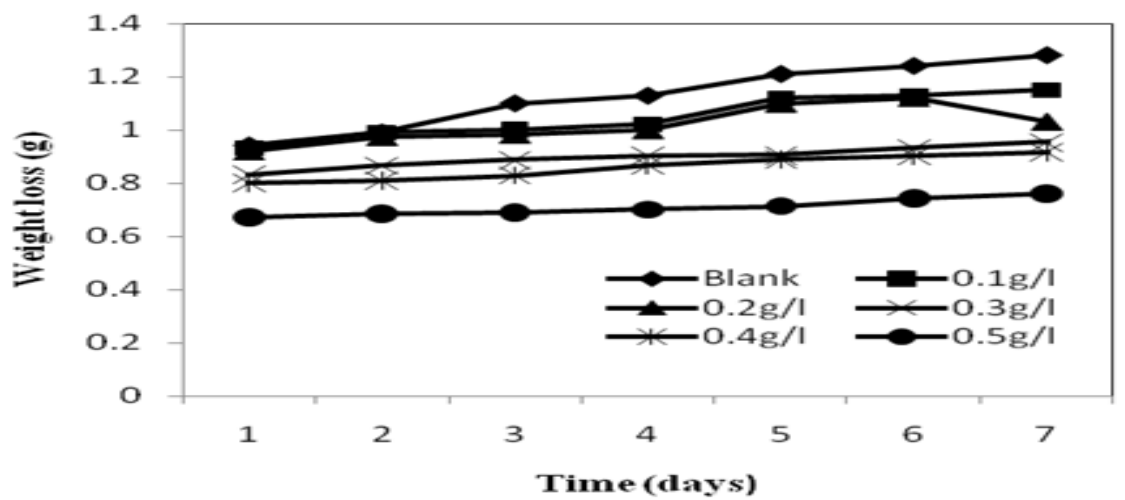

Figure 1: Plot of weight loss against time for aluminium corrosion in $1.5 \mathrm{M} \mathrm{H}_{2} \mathrm{SO}_{4}$ devoid of and containing different concentrations of the fruit extract at $30^{\circ} \mathrm{C}$.

The corrosion rates of the aluminium coupons in $1.5 \mathrm{M} \mathrm{H}_{2} \mathrm{SO}_{4}$ in the absence and presence of different concentrations of inhibitor (Chrysophyllum albidum fruit extract) were determined. The results obtained are presented in Table 1. From the Table, rate of corrosion decreased with increasing concentration of the Chrysophyllum albidum fruit extract. This indicates that Chrysophyllum albidum fruit extract in the solution inhibits the corrosion of aluminium in $\mathrm{H}_{2} \mathrm{SO}_{4}$ and that the extent of corrosion inhibition depends on the amount of the extract present.

Also shown in Table 1 are the calculated values of inhibition efficiency for the Chrysophyllum albidum fruit extract. It is observed that the inhibition efficiency increased with increasing concentration of the Chrysophyllum albidum fruit extract. The maximum inhibition efficiency was observed to be $40.52 \%$ at $0.5 \mathrm{~g} / \mathrm{l}$.

The corrosion inhibition can be attributed to adsorption of molecules of phytochemicals present in the plant on the surface of the metal. The phytochemical composition of the fruit extract from Chrysophyllum albidum was studied by Edem et al., [27]; the peel was shown to contain $58.9 \%$ moisture, $6.1 \%$ protein, $12.4 \%$ lipid, $4.6 \%$ ash, $62.4 \%$ carbohydrate and $14.5 \%$ crude fibre. The pulp contained $67.5 \%$ moisture, $8.8 \%$ protein, $15.1 \%$ lipid, $68.7 \%$ carbohydrate, $4.0 \%$ crude fibre and $3.4 \%$ ash. Analysis of the fruit for minerals showed the peel to contain (in $\mathrm{mg} / 100 \mathrm{~g}$ dry matter): calcium, 250; potassium, 1175; sodium, 12; copper, 2.0; magnesium, 90; zinc, 3.8; iron, 200; and phosphorus, 76.8. The pulp contained (in $\mathrm{mg} / 100 \mathrm{~g}$ dry matter): calcium, 100; potassium, 1175; sodium, 10; copper 2.0; magnesium, 75; zinc, 3.2; iron, 10; and phosphorus, 75.4. The peel contained ascrobic acid $239.1 \mathrm{mg} / 100 \mathrm{~g}$ and the pulp, $446 \cdot 1 \mathrm{mg} / 100 \mathrm{~g}$. Some toxicants were shown to be present. The peel contained $264 \mathrm{mg} / 100 \mathrm{~g}$ tannins and the pulp, $627 \mathrm{mg} / 100 \mathrm{~g}$. The total oxalate content in the peel was $211 \mathrm{mg} / 100 \mathrm{~g}$ and in the pulp, $167 \mathrm{mg} / 100 \mathrm{~g}$. The hydrocyanic acid content was $5.4 \mathrm{mg} / 100 \mathrm{~g}$ in the peel and $6.8 \mathrm{mg} / 100 \mathrm{~g}$ in the pulp. The phytic acid content was $0.8 \mathrm{mg} / 100 \mathrm{~g}$ in the peel and $1.6 \mathrm{mg} / 100 \mathrm{~g}$ in the pulp. Owing to the complex chemical composition of the Chrysophyllum albidum fruit extract, it is quite difficult to assign the inhibitive effect to a particular constituent. However, mutual effects of these compounds and other components present in the Chrysophyllum albidum fruit extract cannot be ruled out. The adsorption of these compounds on the aluminium surface reduces the surface area available for corrosion.

Table 5: Calculated values of corrosion rate $(\mathrm{mm} / \mathrm{yr})$, inhibition efficiency $(\% \mathrm{I})$ and degree of surface coverage $(\theta)$ for Chrysophyllum albidum fruit extract from weight loss data in $1.5 \mathrm{M} \mathrm{H}_{2} \mathrm{SO}_{4}$

\begin{tabular}{|c|c|c|c|c|c|c|c|c|c|c|c|c|}
\hline $\begin{array}{l}\text { Conc.(s) } \\
\text { of }\end{array}$ & \multicolumn{4}{|c|}{$\begin{array}{l}\text { Corrosion Rate }(\mathrm{mm} / \mathrm{yr}) \\
\times 10^{-2}\end{array}$} & \multicolumn{4}{|c|}{$\begin{array}{l}\text { Inhibition Efficiency } \\
(\% \mathrm{I})\end{array}$} & \multicolumn{4}{|c|}{$\begin{array}{l}\text { Degree of surface coverage } \\
\qquad(\theta)\end{array}$} \\
\hline $\begin{array}{l}\text { CAFE } \\
(\mathrm{g} / \mathrm{l})\end{array}$ & $30^{\circ} \mathrm{C}$ & $40^{\circ} \mathrm{C}$ & $50^{\circ} \mathrm{C}$ & $60^{\circ} \mathrm{C}$ & $30^{\circ} \mathrm{C}$ & $40^{\circ} \mathrm{C}$ & $50^{\circ} \mathrm{C}$ & $60^{\circ} \mathrm{C}$ & $30^{\circ} \mathrm{C}$ & $40^{\circ} \mathrm{C}$ & $50^{\circ} \mathrm{C}$ & $60^{\circ} \mathrm{C}$ \\
\hline Blank & 12.36 & 16.71 & 18.35 & 20.28 & & & & & & & & \\
\hline 0.1 & 11.10 & 15.21 & 16.83 & 18.82 & 10.20 & 9.00 & 8.30 & 7.20 & 0.10 & 0.09 & 0.08 & 0.07 \\
\hline 0.2 & 9.96 & 13.99 & 15.60 & 17.40 & 19.41 & 16.30 & 15.00 & 14.20 & 0.19 & 0.16 & 0.15 & 0.14 \\
\hline 0.3 & 9.22 & 12.78 & 14.65 & 16.47 & 25.41 & 23.50 & 20.15 & 18.80 & 0.25 & 0.24 & 0.20 & 0.19 \\
\hline 0.4 & 8.84 & 12.37 & 14.20 & 16.00 & 28.50 & 26.00 & 22.63 & 21.10 & 0.29 & 0.26 & 0.23 & 0.21 \\
\hline 0.5 & 7.35 & 10.43 & 12.46 & 14.50 & 40.52 & 37.60 & 32.10 & 2852 & 41 & 038 & 0.32 & 0.29 \\
\hline
\end{tabular}

\subsection{Thermometric studies}

Thermometric methods have proved to be of considerable value and help in studying corrosion behaviour of a number of metals and alloys in various corroding environments [28, 29]. The technique is also useful in evaluating the inhibition efficiency of a number of organic substances [30, 31]. Results obtained using 
thermometric methods have been confirmed by several research groups and by other well-established methods such as weight loss [29, 31, 32], potentiostatic [33] and polarization measurement [34].

Fig. 2 shows the plot of temperature versus time for the corrosion reaction of aluminium in $1.5 \mathrm{M}$ $\mathrm{H}_{2} \mathrm{SO}_{4}$ in the absence and presence of different concentrations of Chrysophyllum albidum fruit extract. Inspection of the figure revealed that the dissolution of aluminium starts after a certain time from the immersion of the aluminium coupons in the test solution as evident in the constant temperature with time. It may be expected that this time corresponds to the period required by the acid to destroy the pre-immersion oxide film and is known as the 'incubation period'. After the consumption of the pre-immersion oxide film, the temperature of the system rises gradually due to the exothermic corrosion reaction to reach a maximum value, $T_{\mathrm{m}}$.

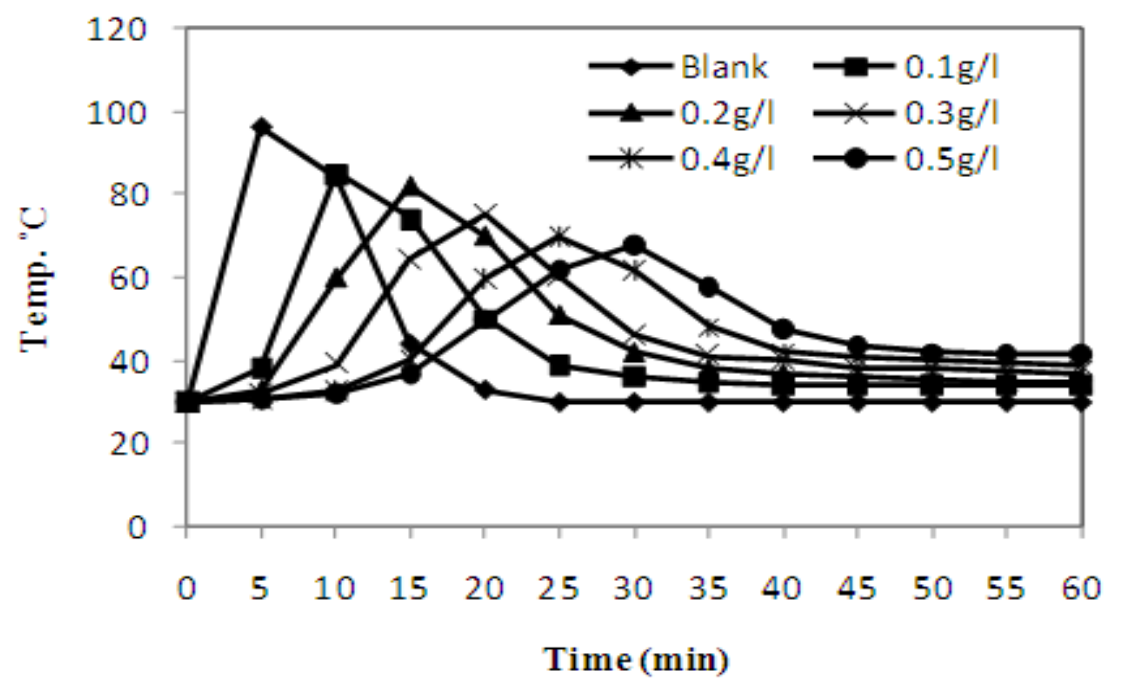

Figure 2: Temperature - time curves for aluminium corrosion in $1.5 \mathrm{M} \mathrm{H}_{2} \mathrm{SO}_{4}$ in the absence and presence of Chrysophyllum albidum fruit extract of different concentrations.

It is seen from Fig. 2 that the maximum temperature $T_{\mathrm{m}}$ was attained at a very short time $(t)$ by the free acid solution. This corresponds to a reaction number (RN) of $13.20^{\circ} \mathrm{C} \mathrm{min}^{-1}$ (Table 2). Further inspection of Fig. 2 revealed that on addition of the Chrysophyllum albidum fruit extract the maximum temperature attained decreased and the time required to reach it increased correspondingly. This is an indication that the various additives inhibit the corrosion of $\mathrm{Al}$ in the acidic environment, probably by adsorption on the metal surface [35]. The extent of inhibition depends on the degree of coverage of the metal by the adsorbed molecules. Strong adsorption is noted at higher concentration of Chrysophyllum albidum fruit extract as depicted by further decrease in maximum temperature $\left(T_{\mathrm{m}}\right)$ attained and a corresponding increase in time $(t)$ taken to reach it, and both factors cause a large decrease in the RN of the system (Table 2). The temperature of all the systems decreased after reaching their maximum values. This could be attributed to decreasing corrodent concentration with increasing reaction time, which in turn decreased the corrosion rate, hence, a decrease in quantity of heat evolved. The results obtained in this study corroborate those of other studies [26, 36].

Table 2: Calculated values of Reaction Number and Percentage Reduction in $\mathrm{RN}$ for Al dissolution in $1.5 \mathrm{M}$ $\mathrm{H}_{2} \mathrm{SO}_{4}$ containing Chrysophyllum albidum fruit extract from thermometric method

\begin{tabular}{|c|c|c|}
\hline Concentrations of CAFE (g/l) & $\begin{array}{c}\text { Reaction Number }(\mathrm{RN}) \\
\left({ }^{\circ} \mathrm{C} \mathrm{min}^{-1}\right)\end{array}$ & $\begin{array}{c}\text { \% Reduction in RN } \\
\text { (Inhibition efficiency) }\end{array}$ \\
\hline Blank & 13.20 & - \\
\hline 0.1 & 5.50 & 58.33 \\
\hline 0.2 & 3.47 & 73.71 \\
\hline 0.3 & 2.25 & 82.96 \\
\hline 0.4 & 1.60 & 87.88 \\
\hline 0.5 & 1.27 & 90.38 \\
\hline
\end{tabular}

Table 2 shows the calculated values of reaction number (RN) and the percentage reduction in reaction number (inhibition efficiency) for the various systems investigated. It is very clear from the Table that reaction number decreased in the presence of Chrysophyllum albidum fruit extract compared to the blank solution. Also, the percentage reduction in reaction number increased with increase in concentration of Chrysophyllum albidum 
fruit extract. This assertion is also corroborated by weight loss measurements. Comparing the values of the inhibition efficiency calculated from weight loss and thermometric methods for the Chrysophyllum albidum fruit extract (Tables 1 and 2), it can be seen that the values obtained from weight loss technique are lower while those obtained by the thermometric method are higher. This may be attributed to the difference in time required to form an adsorbed layer of the inhibitor on the metal surface that can inhibit corrosion. Also, values of corrosion rate from weight loss method represent average values while those of thermometric method represent the instantaneous values.

\subsection{Adsorption/thermodynamic studies}

Values of degree of surface coverage $\theta$ were evaluated at different concentrations of the Chrysophyllum albidum fruit extract in $1.5 \mathrm{M} \mathrm{H}_{2} \mathrm{SO}_{4}$ solution from weight loss measurements (Table 1). The values of surface coverage for the Chrysophyllum albidum fruit extract were fitted into Temkin adsorption isotherm model, which has the form [37]:

$$
\exp (-2 a \theta)=K C
$$

where $a$ is molecules interaction parameter, $\theta$ is the degree of surface coverage, $K$ is equilibrium constant of adsorption process and $C$ is the concentration of Chrysophyllum albidum fruit extract. $K$ is related to the free energy of adsorption by the equation:

$$
K=(1 / 55.5)\left[\exp \left(-\Delta G_{\text {ads }}^{\mathrm{o}} / \mathrm{RT}\right)\right]
$$

The plot of surface coverage $(\theta)$ as a function of logarithm of concentration of Chrysophyllum albidum fruit extract is shown in Fig. 3. From the plot, straight lines were obtained for Chrysophyllum albidum fruit extract suggesting that its adsorption on the aluminium surface follows Temkin adsorption isotherm. This result confirms the assumption that the corrosion inhibition of the fruit extract from Chrysophyllum albidum is attributed to the adsorption of molecules of phytochemicals present in the fruit extract on the surface of the metal.

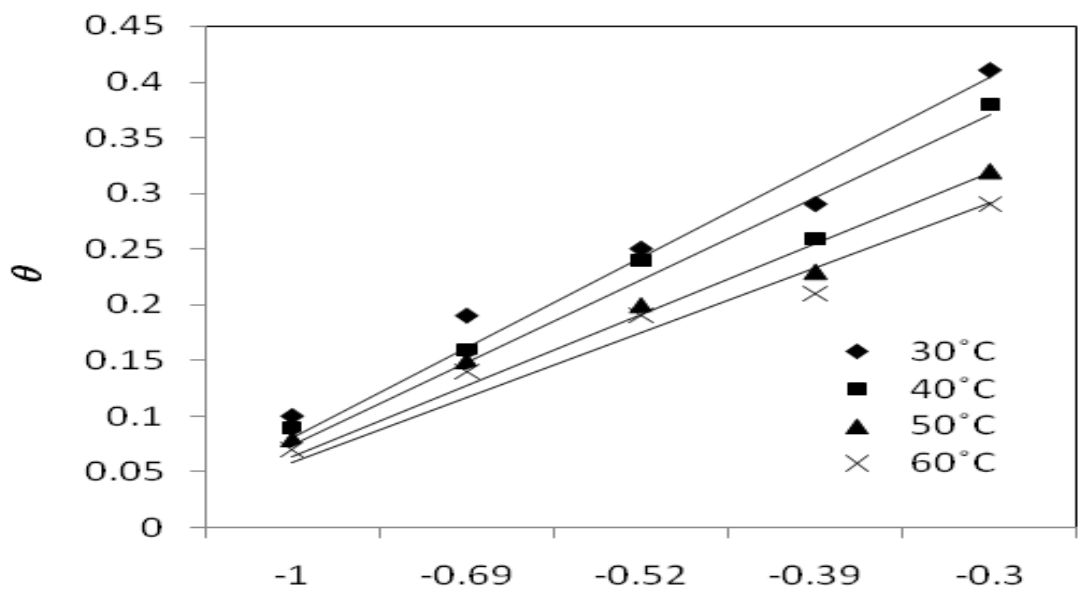

$\log C$

Figure 3: The plot of surface coverage $(\theta)$ as a function of logarithm of Chrysophyllum albidum concentrations at $30-60^{\circ} \mathrm{C}$ in $1.5 \mathrm{M} \mathrm{H}_{2} \mathrm{SO}_{4}$

The calculated values of molecular interaction parameter ' $a$ ' and equilibrium constant of adsorption process $K$, obtained from Temkin's plot is shown in Table 3 . The values of ' $a$ ' are negative in all cases showing that repulsion exist in adsorption layer [38]. Values of $K$ decreased with increasing temperature suggesting that the inhibitor is physically adsorbed on the surface.

Generally, $K$ denotes the strength between adsorbate and adsorbent. Large values of $K$ imply more efficient adsorption and hence better inhibition efficiency [39].

Values of free energy of adsorption, $\Delta G_{\text {ads }}^{\mathrm{o}}$ were obtained from Equation (7). The values obtained are shown in Table 3. Results presented in the table indicate that the values of $\Delta G_{\text {ads }}^{\mathrm{o}}$ are negative in all cases indicating spontaneous adsorption of the inhibitor molecules. Values of $\Delta G_{\text {ads }}^{\mathrm{o}}$ also indicate that the inhibitor function by physically adsorbing on the surface of the metal. 
Table 3: Some thermodynamic parameters and adsorption coefficients for aluminium corrosion of Chrysophyllum albidum fruit extract in $1.5 \mathrm{M} \mathrm{H}_{2} \mathrm{SO}_{4}$

\begin{tabular}{|c|c|c|c|c|}
\hline \multirow{2}{*}{ Inhibitor } & \multirow{2}{*}{ Temp. $^{\circ} \mathrm{C}$} & \multicolumn{3}{|c|}{ Temkin } \\
\cline { 3 - 5 } & & $\Delta G_{\text {ads }}^{\text {o }}\left(\mathrm{KJ} \mathrm{mol}^{-1}\right)$ & $a$ & $k$ \\
\hline CAFE & 30 & -4.48 & -1.220 & 1.08 \\
\hline & 40 & -4.60 & -1.282 & 1.05 \\
\hline & 50 & -4.77 & -1.613 & 1.08 \\
\hline & 60 & -4.87 & -1.563 & 1.03 \\
\hline
\end{tabular}

Generally, values of $\Delta G_{\text {ads }}^{\mathrm{o}}$ up to $-20 \mathrm{~kJ} \mathrm{~mol}^{-1}$ are consistent with electrostatic interaction between charged molecules and a charged metal (which indicates physical adsorption) while those more negative than $40 \mathrm{~kJ} \mathrm{~mol}^{-1}$ involves charge sharing or transfer from the inhibitor molecules to the metal surface to form a coordinate type of bond (which indicates chemisorption) [40,41]. Physical adsorption is a result of electrostatic attraction between charged metal surface and charged species in the bulk of the solution. Adsorption of negatively charged species is facilitated if the metal is positively charged. Positively charged species can also protect the positively charged metal surface acting with a negatively charged intermediate such as acid anions adsorbed on the metal surface [41].

Values of enthalpy of activation $\Delta H^{\circ}$ and entropy of activation $\Delta S^{\circ}$ were obtained from Fig. 4, the transition state Equation (8):

$$
C R=(R T / N h) \exp \left(\Delta S^{o} / R\right) \exp \left(-\Delta H^{o} / R T\right)
$$

where $h$ is the Planck's constant, $N$ is the Avogadro's number, $T$ is the absolute temperature and $R$ is the universal gas constant. A plot of $\log (C R / T)$ as a function of $1 / T$ was made and straight lines were obtained. $\Delta H^{\mathrm{o}}$ and $\Delta S^{\mathrm{o}}$ were computed from the slope and intercept respectively from the linear plot. The average values for $\Delta H^{\circ}$ and $\Delta S^{\circ}$ obtained in the presence of the Chrysophyllum albidum fruit extract were $4.932 \mathrm{~kJ} \mathrm{~mol}^{-1}$ and $0.0270 \mathrm{~kJ} \mathrm{~mol}^{-1} \mathrm{~K}^{-1}$ respectively.

The positive sign of the $\Delta H^{\circ}$ reflects the endothermic nature of the aluminium dissolution process in the presence of the fruit extract, while the negative sign of $\Delta S^{\circ}$ shows increase in the system order [36].

\subsection{Effect of temperature}

The effect of temperature on the corrosion rate of aluminium in free acid and in the presence of different concentrations of Chrysophyllum albidum fruit extract was studied in the temperature range of $30-$ $60^{\circ} \mathrm{C}$ using weight loss measurements. In examining the effect of temperature on the corrosion process in the presence of the fruit extract, the Arrhenius equation was used:

$$
\log C R=\frac{-E_{\mathrm{a}}}{2.303 R T}+\log A
$$

where $C R$ is the corrosion rate, $E_{\mathrm{a}}$ is the apparent activation energy, $R$ is the molar gas constant, $T$ is the absolute temperature and $A$ is the frequency factor. 


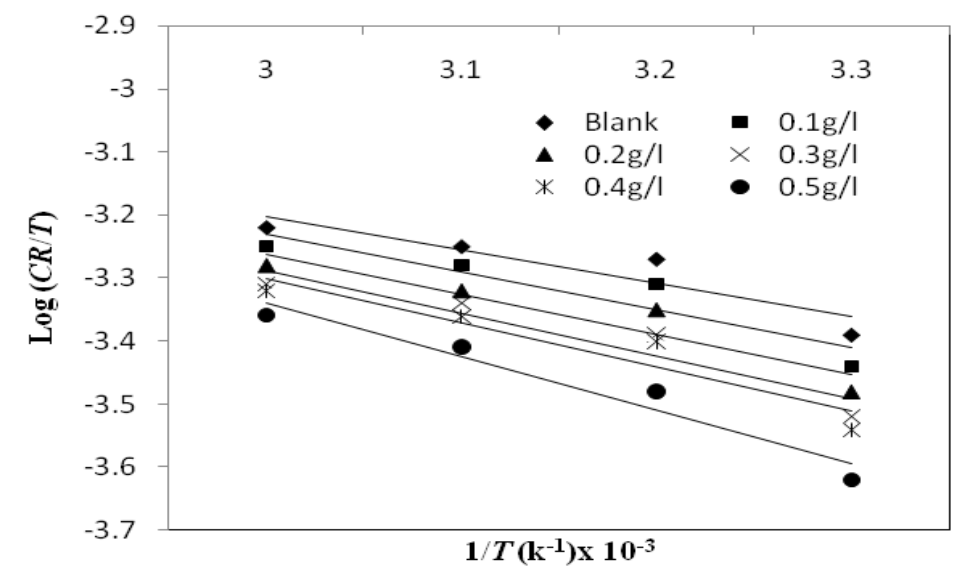

Figure 4: Transition state plot for Chrysophyllum albidum fruit extract in $1.5 \mathrm{M} \mathrm{H}_{2} \mathrm{SO}_{4}$

Fig. 5 represents Arrhenius plot (as $\log C R$ versus $1 / T$ ) for aluminium corrosion in $1.5 \mathrm{M} \mathrm{H}_{2} \mathrm{SO}_{4}$ in the absence and presence of various concentrations of Chrysophyllum albidum fruit extract. Straight lines were obtained with slope equal to $-E_{\mathrm{a}} / 2.303 R$. Values of $E_{\mathrm{a}}$ for the corrosion reaction in the absence and presence of Chrysophyllum albidum fruit extract were calculated and are presented in Table 4. Inspection of the table shows that the presence of the fruit extract increased values of $E_{\mathrm{a}}$ when compared to its absence (blank) indicating the adsorption of Chrysophyllum albidum fruit extract on the surface of the metal.

The higher value of the activation energy of the process in an inhibitor's presence when compared to that in its absence is attributed to its physisorption, while the opposite is the case with chemisorption [42, 43].

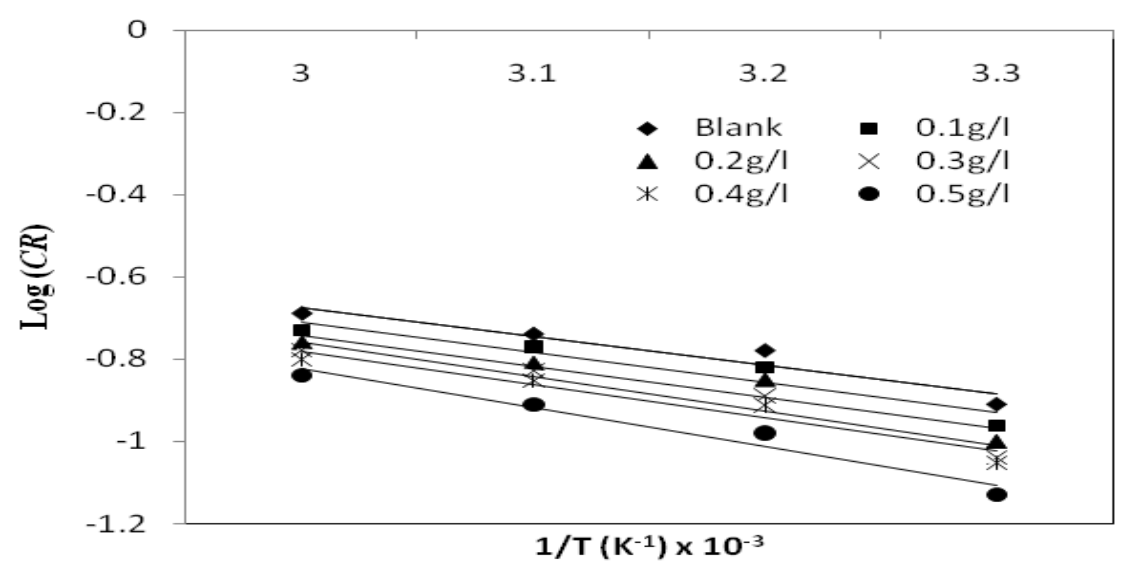

Figure 5: Arrhenius plot (as $\log C R$ versus 1/T) for aluminium corrosion in $1.5 \mathrm{M} \mathrm{H}_{2} \mathrm{SO}_{4}$ in the absence and presence of various concentrations of Chrysophyllum albidum fruit extract.

Table 4: Values of Activation Energy for aluminium corrosion in $1.5 \mathrm{M} \mathrm{H}_{2} \mathrm{SO}_{4}$ in the absence and presence of Chrysophyllum albidum fruit extract

\begin{tabular}{|c|c|}
\hline $\begin{array}{c}\text { Concentrations of CAFE } \\
(\mathrm{g} / \mathrm{l})\end{array}$ & $\begin{array}{c}\text { Activation Energy } E_{\mathrm{a}} \\
\left(\mathrm{KJ} \mathrm{mol}^{-1}\right)\end{array}$ \\
\hline Blank & 11.81 \\
\hline 0.1 & 12.45 \\
\hline 0.2 & 12.77 \\
\hline 0.3 & 14.04 \\
\hline 0.4 & 13.40 \\
\hline 0.5 & 16.28 \\
\hline
\end{tabular}


IV

CONCLUSIONS

The present study provides new information on the inhibition characteristics of Chrysophyllum albidum fruit extract under the specified conditions. Chrysophyllum albidum fruit extract acts as an inhibitor of aluminium corrosion in $1.5 \mathrm{M} \mathrm{H}_{2} \mathrm{SO}_{4}$ solution. The inhibition efficiency increased with increase in inhibitor concentration but decreased with increase in temperature. The inhibiting effect of the Chrysophyllum albidum fruit extract could be attributed to the presence of some phytochemical constituents in the fruit extract which is adsorbed on the surface of the aluminium. It is a cheap, eco-friendly, non-toxic, renewable material, readily and abundantly available corrosion inhibitor, though biodegradable, could be used in the elongation of service life of aluminium structures deployed in service in aggressive environment.

\section{REFERENCES}

[1] J.A. Bardwell, B. MacDoughall, Electrochim. Acta, 34, 1989, 229.

[2] E.E. Oguzie, E.E. Ebenso, Pigm. Resin Technol., 35, 2006, 30.

[3] G. Mu, X. Li, J. Colloid Interf. Sci., 289, 2005, 184.

[4] M. Lebrini, F. Bentiss, H. Vezin, M. Lagrenee, Corros. Sci., 48, 2006, 1279.

[5] E.E. Oguzie, Corros. Sci., 50, 2008, 2993.

[6] E.E. Oguzie, Mater Chem Phys., 93, 2006, 441.

[7] P.B. Raja, M.G. Sethuraman, Mater Corros., 60, 2009, 1.

[8] M.K. Sharma, P. Arora, S. Kumar, S.P. Mathur, R. Ratnani, Corros. Eng. Sci.Technol., 43, 2008, 213.

[9] E.E. Oguzie, Port. Electrochim. Acta, 26, 2008, 303.

[10] A.Y. El-Etre, J. Colloid Interf. Sci., 314, 2007, 578.

[11] P.B. Raja, M.G. Sethuraman, Surface Review Lett., 14, 2007, 1157.

[12] O.K. Abiola, A.O. James, Corros. Sci., 51, 2009, 1879.

[13] P.C. Okafor, M. E. Ikpi, I.E. Uwah, E.E. Ebenso, U.J. Ekpe, S.A. Umoren, Corros. Sci.,50, 2008, 1879.

[14] S.A. Umoren, I.B. Obot, E.E. Ebenso, N.O. Obi-Egbedi, Port. Electrochim. Acta, 26, 2008, 199.

[15] S.A. Umoren, I.B. Obot, E.E. Ebenso, P.C. Okafor, Port. Electrochim. Acta, 26, 2008, 267.

[16] S.A. Umoren, I.B. Obot, L.E. Akpabio, S.E. Etuk, Pigment \& Resin Technol. 37, 2008, 98.

[17] S.A. Umoren, I.B. Obot, E.E. Ebenso, P.C. Okafor, O. Ogbobe, E.E. Oguzie, Anti-Corros. Meth. Mater.,53, 2006, 277.

[18] S.A. Umoren, I.B. Obot, E.E. Ebenso, N.O. Obi-Egbedi, Desalination, 247, 2009, 561.

[19] I.B. Obot, N.O. Obi-Egbedi, Port. Electrochim. Acta, 27, 2009, 517.

[20] P.B. Raja, M.G. Sethuraman, Mater. Lett., 62, 2008, 113.

[21] U.J. Ekpe, E.E. Ebenso, and B.S. Antia, West. Afri. J.Biol Appl Chem., 41, 1999, 16-20.

[22] NACE. Nat. Assoc. Corros. Eng., 1984.

[23] NACE. Nat. Assoc. Corros. Eng., Standard TMO169-95 (Item No. 21200).

[24] B.N. Oza, and R.S. Sinha, Trans SAEST, 17(1), 1982, 281-285.

[25] R.K. Upadhyay, and S.P. Mathur, E-J. Chem., 4(3), 2007, 408-414.

[26] A.Y. El-Etre, Corros. Sci., 43, 2001, 1031-1039.

[27] D.O. Edem, O.U. Eka, and E.T. Ifon, Food Chem., 14, 1984, 303-311

[28] S.A. Umoren, O. Ogbobe, and E.E. Ebenso, Bull. Electrochem., 22(4), 2006,155-157.

[29] M.N. Moussa, A.S. Fouda, F.I. Taha, and A. Eluenaa, Bull. Korean Chem. Soc., 9(4), 1988, 191-195.

[30] E.E. Ebenso, Nig. Corros. J. (NCJ), 1, 1998, 29-43.

[31] S.A. Umoren, O. Ogbobe, and E.E. Ebenso, Trans SAEST, 41, 2006, 74-81.

[32] A.O. James, N.C. Oforka, and O.K. Abiola, Intl. J. Electrochem.Sci., 2, 2007, 278-284

[33] A.K. Maayta, N.A.F. Al-Rawashdeh, Corros. Sci., 46, 2004, 1129-1140.

[34] S.S. Abd El-Rehim, M.A.M. Ibrahim, and K.F. Khaled, J. Appl. Electrochem.,29, 1999, 593-599.

[35] S.A. Umoren, I.B. Obot, E.E. Ebenso, P.C. Okafor, O. Ogbobe, and E.E. Oguzie, Anti-Corros. Meth. Mater., 53(5), 2006, 277-282.

[36] A.Y. El-Etre, Corros. Sci., 45, 2003, 2485-2495.

[37] M. Sahin, S. Bilgic, H. Yilmaz, Appl. Surf. Sci., 195, 2002, 1-7.

[38] S.A. Umoren, E.E. Ebenso, P.C. Okafor, U.J. Ekpe, and O. Ogbobe, J. Appl. Polym. Sci., 10(5), 2007, 2810.

[39] S.A.M. Refay, F. Taha, and A.M. Abd El-Malak, Appl. Surf. Sci., 236, 2004,175-185.

[40] I. Dehri, and M. Ozcan, Mater Chem Phys., 98, 2006, 316-323.

[41] A. Popova, E. Sokolova, S. Raicheva, M. Christov, Corros. Sci., 45, 2003, 33-58.

[42] M. Elayyachy, B. Hammouti, and A. El Idrissi, Appl Surf. Sci., 249, 2005, 176-182.

[43] M.S. Morad, A.M. Kamal, El - Dean, Corros. Sci., 48, 2006, 3398-3412. 